\section{BJSM: Serving national sports medicine and sports physiotherapy societies and major international sporting organisations}

\author{
Karim M Khan
}

BJSM's 22 annual issues and terabytes of digital media content have a clear mandate-to serve clinicians who work in the broad field of 'sports and exercise medicine'. The term 'medicine' includes the wide health community including many kinds of practitioners including physiotherapists, doctors, athletic trainers, personal trainers, etc. The journal should serve everyone who aims to improve health through preventing injury and promoting physical activity in an ethical manner. Sports injury and illness prevention, treatment and health promotion through physical activity are core business.

Thirteen national clinical organisations that themselves serve sports medicine/ sports physiotherapy currently provide $B J S M$ as a member benefit. Clinicians from South Africa to the Arctic Circle and from Zurich to Los Angeles/Waikiki access the journal online through their member websites (http://bjsm.bmj.com/site/about/). $B J S M$ is accessed over 3.8 million times annually-10 000 hits a day, every day and going up.

Aspetar Orthopaedic and Sports Medicine Hospital, Doha, Qatar

Correspondence to Dr Karim M Khan, Aspetar Orthopaedic and Sports Medicine Hospital, Doha, Qatar; karim.khan@aspetar.com

\section{MEMBER SOCIETY EDITORS ENSURE} BJSM'S RELEVANCE TO CLINICIANS

You should find the journal relevant because member society editors play a critical role in choosing content. Each of the member societies guides one issue of $B J S M$ and associated digital media (podcasts, video, blogs, Twitter and Facebook). That's why one issue of BJSM focused on sports injury prevention initiatives in skiing (via the Norwegian sports physiotherapists and sports physicians-http:// bjsm.bmj.com/content/48/9.toc). One issue focused on patellofemoral pain and its treatment (via the Swiss Sports Physiotherapy society-http://bjsm.bmj. com/content/48/6.toc). And the American Medical Society for Sports Medicine (AMSSM) published an issue focusing on the accurate interpretation of ECGs in athletes $^{1}$ as well as creating a BMJ Learning module freely accessible to the entire world-http://learning.bmj.com/ learning/course-intro/.html? courseId $=1004223$.

\section{MEMBER SOCIETY BENEFIT- REACHING A WIDE AUDIENCE}

$B J S M$ affiliation provides member societies a convenient and authoritative way to promote sports medicine and physiotherapy messages. As examples, the AMSSM has produced Guidelines on the management of concussion (http://bjsm.bmj.com/content/47/ 1/15.full? sid = 8ba5e38f-0e22-4573-b4fb0ad4dcf1f963), care of the female athlete (http://bjsm.bmj.com/content/48/4/289.full) and prevention of overuse injuries and burnout in youth sports (http://bjsm.bmj. com/content/48/4/287.full).

\section{SPORTS INJURY AND ILLNESS PREVENTION SUPPORTED BY THE INTERNATIONAL OLYMPIC COMMITTEE}

The International Olympic Committee is committed to sports injury prevention and health protection for sports people. One vehicle for promoting this is via four annual issues of BJSM branded as 'Injury Prevention and Health Protection' (IPHP) special issues. Look for the Olympic Rings on the covers. Recent issues covered clinical care at the Sochi Games (http:/ bjsm.bmj.com/content/48/1.toc) and the World Conference on Injury and Illness in Sport (http://bjsm.bmj.com/content/48/7.toc).

In summary, let us know how BJSM can work for you-email karim.khan@ubc.ca to send suggestions. And follow @BJSM_BMJ for regular Twitter updates.

Competing interests None.

Provenance and peer review Not commissioned; internally peer reviewed.

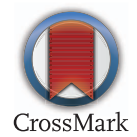

To cite Khan KM. Br J Sports Med 2014;48:939.

Accepted 20 April 2014

Br J Sports Med 2014:48:939

doi:10.1136/bjsports-2014-093791

\section{REFERENCE}

1 Drezner JA, Ackerman MJ, Anderson J, et al. Electrocardiographic interpretation in athletes: the 'Seattle Criteria'. Br J Sports Med 2013;47:122-4. 